\title{
Johannes Calvyn en die leer van die uitverkiesing Enkele opmerkings
}

\author{
AD Pont \\ Lesing gehou by die opening van die werksaamhede van die \\ Teologiese Fakulteit, Afd. A. 17 Februarie 1981.
}

\section{INLEIDENDE OPMERKINGS}

Die leer van die uitverkiesing is een van die basiese waarhede van die Skrif wat vandag byna nie meer in die teologiese debat gehoor word nie. Dit is wel merkwaardig omdat hierdie saak van die uitverkiesing, die Skriftuurlike gegewens in verband met God en sy regering van die heelal, die sondeval en die sonde van die mens, die evangelie van die verlossing deur Jesus Christus en die geloof as gawe van God in 'n Bybelse samehang plaas. Die waarskynlikste rede waarom hierdie leer van die uitverkiesing so op die agtergrond geraak het is die popularisering van die metodisme en die metodisties-geïnfekteerde teologieë in die struktuur van die Wêreldraad van Kerke'. In hierdie èn in die genitief-teologieë van ons tyd word die sondeval en die sonde van die mens feitlik nie meer na vore gebring nie sodat die verlossing wat daar gepreek word nie noodwendig ' $n$ verlossing-uit-die-sonde hoéf te wees nie. Die verskuiwings in die moderne teologiese gesprek bring dan ook mee dat die verlossing wat geleer word, na die horisontale vlak getrek word. Op dié manier word die Bybelse boodskap vervlak en van sy troos en inspirasie beroof.

Dit kan miskien ' $n$ bydrae lewer tot die voortgaande teologiese gesprek om weer 'n keer aandag te gee aan die leer van die uitverkiesing juis omdat hierdie deel van die Bybelse boodskap op rondliggende Bybelse begrippe gebou is. Vir die doeleindes van hierdie uiteensetting word daar na 'n paar fasette van die kerkvader Johannes Calvyn se uiteensetting gekyk. Dit is egter belangrik om daarop te let dat die leer van die uitverkiesing nie gesien moet word as die sleutel tot Calvyn se teologie nie maar as ' $n$ onderdeel van sy teologie waar hy 'n reeks Bybelse waarhede saamvat'.

\section{DIE PLEK VAN DIE LEER VAN DIE UITVERKIESING BY CALVYN}

Sonder om op die res van die betoog vooruit te loop, is dit tog 
interessant om vas te stel dat in die geheel van sy teologie, die leer van die uitverkiesing nie 'n baie prominente plek inneem nie. In die eerste uitgawe van Calvyn se Institutio christianae religionis van 1536 word die leerstuk van die uitverkiesing nog nie apart behandel nie. Hy noem dit by sy uitleg van die Apostolicum by artikel 2 en dan ook by sy omskrywing van die kerk waar hy na die kerk verwys as "die eindtotaal van uitverkorenes, of hulle nou ook al engele of mense is." Hier bespreek hy die uitverkiesing as die fondament van die kerk ${ }^{3}$.

In die uitgawe van die Institusie van 1539 word die eerste maal 'n aparte hoofstuk (Cap. 8), De praedestinatione et providentia aan die uitverkiesing gewy. Daarna het Calvyn in 'n aantal geskrifte hierdie leer verdedig en bespreek in die oortuiging dat hierdie Bybelse waarheid nie aan die misverstand uitgelewer mag word nie*.

Hierdie leerstuk, so het Calvyn benadruk, kan alleen in en deur die geloof verstaan word want dit wil slegs 'n skriftuurlike antwoord gee op die vraag waar die verlossing van die mens vandaan kom. Dit is duidelik dat hierdie vraag vrae opwerp wat nie met die menslike verstand alleen verklaar kan word nie. Dit gaan immers hier om sulke belangrike sake soos God se almag en die verantwoordelikheid van die mens, dit gaan om die mag en die effek van die duistere mag van die sonde, dit gaan om Jesus Christus en die geloof in Hom. Geen wonder dat Calvyn voortdurend waarsku dat die filosofie en die rasionele spekulasie hier nie vrugbaar gebruik kan word maar dat slegs in geloof die waarhede wat die Skrif self hieroor openbaar na vore gebring kan word ${ }^{5}$.

Daarom is dit ook insiggewend dat Calvyn in die finale uitgawe van die Institusie van 1559 die praedestinatio ná die leer oor die geloof in Bk. III, 21-24 behandel. Daar skei hy dan ook die leer van die providentia en die praedestinatio wat hy in 1539 en 1544 as twee aparte stukke saam in dieselfde hoofstuk behandel het. In 1559 kom die providentia voor by die leer aangaande God in Bk. I, 16-18. In sy skeiding van die providentia en die praedestinatio kan 'n duidelike afgrensing ten opsigte van Thomas Aquinas gesien word en ook teenoor Zwingli wat die praedestinatio weer aan die providentia ondergeskik maak ${ }^{6}$. Dit is nog net nodig om hiér weer te stel dat Calvyn suiwer vanuit 'n praktiese, pastorale situasie tot die bespreking van die leer van die uitverkiesing kom. Dit gaan nooit, by die bespreking van die uitverkiesing om 'n poging tot metafisiese spekulasie nie maar om méér lig te werp op die leer van die regverdiging deur die geloof alleen èn om 'n teologiese basis vir die ekklesiologie te vind ${ }^{7}$. Daarom sê Calvyn, as hy die leerstuk begin bespreek ${ }^{8}$ :

"Met betrekking tot die feit dat die verbond van die lewe nie sonder onderskeid aan alle mense verkondig word nie en dat ook hulle aan wie dit verkondig word dit nie gelyk of voortdu- 
rend op dieselfde manier ontvang nie, juis in daardie onderskeid word die wonderlike hoogheid van God se oordeel openbaar. Want dit is sonder twyfel dat ook hierdie verskeidenheid gegrond is in God se ewige verkiesing. Terwyl dit duidelik is dat dit deur God se wil geskied dat aan sommige die saligheid aangebied word en ander die toegang tot die saligheid versper word, is dit ook waar dat hier groot en moeilike vraagstukke bestaan. Die vraagstukke kan alleen verklaar word as die gelowiges ten opsigte van die verkiesing en uitverkiesing seker weet wat hulle behoort te weet."

\section{DIE OMSKRYWING VAN DIE LEER}

Die uitverkiesing is en bly vir Calvyn primêr 'n leer wat hy na vore bring omdat dit in die Skrif voortkom, dit is 'n geopenbaarde waarheid en nie iets wat die mens self, vanuit sy eie kennis, na vore kan bring nie?. Die uitverkiesing èn die ewige wil van God is vir Calvyn se siening baie nou aan mekaar gekoppel. Baie duidelik stel Calvyn dat die voorsienigheid van God alles bepaal. Daar is of gebeur niks wat God nie wil of doen nie. Dit word gou duidelik as ons let op die drie omskrywings van die uitverkiesing wat Calvyn gee. In Bk. IlI 5 stel Calvyn:

"Die predestinasie waardeur God sommige mense tot die hoop van lewe aanneem en ander tot die ewige dood veroordeel, mag deur niemand wat as 'n gelowige beskou wil word, sondermeer verloën word nie. Dié leer word egter met baie spitsvondighede omring en dit veral deur hulle wat die vooraf-kennis van God as oorsaak van die voor-verordinering wil sien. ... Ons omskryf die predestinasie dan as die ewige besluit van God waardeur $\mathrm{Hy}$ self vasgestel het wat $\mathrm{Hy}$ wil wat van elke mens sal word. Alle mense word nie onder gelyke voorwaardes geskep nie maar sommige word vóóraf tot die ewige lewe en ander tot die ewige verdoemenis bestem."

In Bk. III 7 gee Calvyn dan, wat aangedui kan word as ' $n$ tweede omskrywing van die uitverkiesing. Daar sê hy:

"Ons sê dus dat die Skrif duidelik aantoon dat God deur 'n ewige en onveranderlike raad een maal en finaal vasgestel het watter mense $\mathrm{Hy}$ tot saligheid wil aanneem en watter $\mathrm{Hy}$, aan die ander kant, aan die verderf wil prysgee. Ons stel dat hierdie raad, wat die uitverkorenes betref, in sy onverdiende barmhartigheid gegrond is sonder dat enige menslike waardigheid in 
ag geneem is. Diegene wie se toegang tot die lewe gesluit word en wat $\mathrm{Hy}$ aan die verdoemenis oorgee word op grond van sy regverdige, onberispelike en tog ondeurgrondelike oordeel afgewys.

Dan is daar nog 'n derde omskrywing wat gevind word in Calvyn se Defensio adversus calumnias Albert Pighii waar hy stel:

"As ons ons nie vir die evangelie skaam nie, is dit tog nodig om te bely wat duidelik in die evangelie staan naamlik dat God uit sy ewige welbehae ... dié mense wat $\mathrm{Hy}$ wil vir die saligheid bestem het èn, daarmee saamgaande, dat $\mathrm{Hy}$ die ander verwerp het. God het hulle wat Hy deur sy aanneming, wat volkome onverdiend is, waardig geag het met sý Gees verlig sodat hulle die lewe wat in Christus aangebied is, kan ontvang. Die ander mense wat vrywillig ongelowig is, bly die lig van die geloof ontbeer en bly daarom in die duisternis."

By aldrie hierdie omskrywings is die wil van God, die vrye keuse van God, die oorsprong van hierdie skeidingmakende besluit. Dit is op grond hiervan dat Calvyn deur die eeue gehaat is want, so word beweer, hiermee maak Calvyn van God 'n God van willekeur, 'n tiran wat willekeurig die één mens salig maak en die ander een verdoem.

Hierdie stelling dat die wil van God die oorsprong van die uitverkiesing is, het probleme geskep want met die stel van hierdie decretum aeternum kom nou die gevaar van 'n konklusie na vore dat die koms van Jesus Christus nié die beslissende heilsgebeure in die tyd en ewigheid kán wees nie. Dat Calvyn hiertoe kom, is nié so vreemd nie allereers al omdat die decretum aeternum ook in die Skrif genoem word en wel in Ef 1:4 terwyl die verkiesing van God, tot heil en tot verdoemenis in Rom 9:11-21 gevind word.

Hier kan daarop gelet word dat Calvyn natuurlik nié in 'n lugleegte leef en werk nie. Neuser wys tereg daarop dat Calvyn reeds in sy studentejare nie alleen volstandig met die skolastiese teologie kennis gemaak het nie maar ook daarin deurknee is ${ }^{10}$. In 'n uitvoerige studie het Karl Reuter dan ook aangetoon hoe Calvyn, juis ten opsigte van die formulering van wat dit beteken dat die wil van God die uidrukking van God se hele raad is, deur die skolastici beïnvloed is ${ }^{11}$. Die resultaat is dat Calvyn in die Institusie die hele saak van die uitverkiesing van twee kante benader, enersyds van die kant van die leer aangaande God waar hy oor die wil van God en die voorsienigheid handel en andersyds van die kant van Jesus Christus, in die Christologie dus. Neuser sien dit as ' $n$ belangrike storing in Calvyn se uitleg van die leer van die uitverkiesing ${ }^{12}$.

Kortliks kan dan net op dié twee aspekte gewys word. 


\section{DIE WIL VAN GOD EN DIE VOORSIENIGHEID}

As Calvyn dan oor die vooraf-sien en -besluit van God, die providentia dus handel, dan stel hy dat as 'n mens 'n wet of 'n reël neerlê en dan sy wil as die grond en oorsaak van die besluit aangee, dan kan dit as 'n eie-willige of selfs tiranieke optrede omskryf word. Van God kan dit egter nooit gesê word nie omdat sy wil die bron en reël van alle geregtigheid is. Soos hy dit stel ${ }^{13}$ :

"Want as God se wil 'n oorsaak het, dan moet iets aan Hom voorafgaan waaraan $\mathrm{Hy}$ as ' $\mathrm{t}$ ware gebonde is. Dit is goddeloos om so iets selfs maar te dink. God se wil is in so 'n mate die hoogste reël van die regverdigheid, dat alles wat $\mathrm{Hy}$ wil as regverdig aanvaar moet word, juis omdat dit sy wil is.

Wanneer dus gevra word waarom die Here so gemaak het, moet die antwoord wees: omdat $\mathrm{Hy}$ dit so gewil het. En as mens verder gaan en vra: Wáárom het Hy dit gewil, dan vra jy na iets wat groter en hoër as God se wil is en dus nie kan bestaan nie."

Wanneer Calvyn nou oor die providentia handel en in dié verband die wil van God as die oorsprong ook van die uitverkiesing sien, dan doen hy dit omdat hy uit die Skrif leer dat God se wil nooit iets anders kan wees as die uitdrukking van God se heilige en regverdige wese nie ${ }^{14}$. Hierdie konklusie kan vir die mens 'n groot troos wees, hoewel nou die vraag na die vryheid van die mens na vore kom. Hierdie saak beredeneer Calvyn uitvoerig in die Institusie ${ }^{15}$. Met ' $n$ beroep op Spr 16:9 stel Calvyn dat God wel die prima et summa omnium causa is maar dat die mens terselfdertyd ' $n$ dienaar van God se wil is ${ }^{16}$. Daarom verwerp hy ook alle fatalisme ${ }^{17}$.

"... ons word allermins deur God se ewige besluite verhinder om onder sy wil vir onsself te sorg en al ons sake te reël."

Die konklusie waartoe Calvyn dan na 'n uitvoerige en ingewikkelde bespreking kom, is dan ${ }^{18}$ :

"Dit is ... die troos vir die gelowige dat hy insien dat die hemelse Vader alles so onder sy mag het, só deur sy heerskappy en wil regeer, en so deur sy wysheid bestuur, dat niks gebeur wat nie volgens sy beskikking is nie."

Die verskillende vrae wat hier na vore kom, word sorgvuldig deur Calvyn aangestip èn behandel. Tog is dit duidelik dat Calvyn hier verplig word om 'n filosofiese raamwerk vir sy uiteensetting te gebruik omdat hy nie voldoende Skriftuurlike steunpunte vir al sy argumente kan vind nie ${ }^{19}$. Uiteindelik moet ook Calvyn erken dat die 
probleme wat gestel word, nie almal 'n antwoord vanuit die Skrif kan kry nie ${ }^{20}$. Hy sluit sy betoog af met die stelling ${ }^{21}$ :

"Ons wysheid mag niks anders wees nie as 'n poging om met ootmoedige bereidheid om geleer te word alles, sonder uitsondering te aanvaar wat in die Skrif geleer word."

Dit is egter duidelik dat as vanuit die providentia van God na die uitverkiesing toe geredeneer word, 'n argumentslyn getrek word wat baie moeilik is om konsekwent te handhaaf, juis omdat die Skrif self dié saak nie so benader nie.

\section{DIE VERLOSSER EN DIE VERLOSSING IN DIE LIG VAN DIE UITVERKIESING}

Calvyn stel in sy omskrywing van die predestinasie dat die oorsprong daarvan in die wil van God geleë is. Dit kan aanleiding gee tot die opvatting dat die saligheid van die uitverkorenes van ewigheid af vasgestel is. Dit sou dan kan beteken dat daar vir die verlossing van die mens deur Jesus Christus eintlik nié meer 'n plek is nie.

Tog is dit nié wat Calvyn leer nie. In die Institusie stel hy ${ }^{22}$ :

"Dit is dus tóg waar dat God die Vader met sy liefde aan die versoening, wat $\mathrm{Hy}$ in Jesus Christus met ons bewerkstellig het, vóóraf gaan. Of, om dit meer presies te stel, omdat $\mathrm{Hy}$ ons vantevore liefgehad het, daarom versoen $\mathrm{Hy}$ ons daarnà met Hom (I Joh 4:19).

Maar omdat die ongeregtigheid, wat die verontwaardiging van God verdien en wat deur God vervloek en veroordeel is, in ons bly woon totdat Jesus Christus ons met sy dood te hulp kom, dáárom het ons geen volle en vaste verbondenheid met God nie tot op daardie stadium wanneer Jesus Christus ons met God verbind. Inderdaad, as ons daarvan seker wil wees dat God ons liefhet en ons goedgesind is, dan moet ons ons oë op Jesus Christus hou en aan Hom vashou. Want dit is slegs deur Jesus Christus dat ons sonde nie aan ons toegereken word nie ...

Vir hierdie rede sê Paulus dat die liefde, waarmee God ons voor die skepping van die wêreld liefgehad het, altyd in Christus gegrond was (Ef 1:4)."

Hier stel Calvyn dus dat God wèl van alle ewigheid af die uitverkorenes tot die saligheid uitverkies het maar óók dat die uitverkorenes altyd in Christus uitverkies is. Hierdie argument stel Calvyn op 'n ander plek weer so $^{23}$ :

"Hoe is dit moontlik dat God op 'n sekere tyd begin het om dié 
mense in sy guns op te neem wat Hy reeds voor die grondlegging van die wêreld liefgehad het? Dit kan nie anders gebeur nie as dat Hy eers sy liefde betoon nadat Hy deur die bloed van Christus versoen is. Want vanweë die feit dat God die bron van alle geregtigheid is, is dit noodwendig dat die mens, so lank hy nog 'n sondaar is, God tot vyand èn regter het. Daarom is die begin van die liefde van God niks anders as die toereken van die geregtigheid aan die mens nie, soos dit deur Paulus beskryf word (II Kor 5:21): 'Christus was sonder sonde, maar God het Hom in ons plek as sondaar behandel sodat ons, deur ons eenheid met Christus, deur God vrygespreek kan wees (of soos dit in die Grieks staan: sodat ons kan word geregtigheid van God in Hom). Want daarmee sê Paulus dat ons, deur die offer van Christus, onverdiende regverdigheid gekry het, sodat ons wat van nature kinders van die toorn is en deur die sonde van God vervreem is, tóg vir God aanvaarbaar is."

As Calvyn vanuit hierdie hoek die leer van die uitverkiesing uitlê, dan word dit duidelik dat Calvyn hier voluit uitlegger van die Skrif en niks meer is en wil wees nie. Duidelik stel hy dit dat die sondaarmens vanweë sy sonde en skuld niks ánders van God as die ewige verdoemenis durf verwag nie. As God egter, in sy ontferming, uit die massa perditionis wat die mensdom is, mense uitverkies dan gebeur dit nié omdat daardie mense allerlei voortreflikhede besit nie, maar omdat hulle in Christus uitverkies is ${ }^{24}$.

As hierdie aspek van Calvyn se uiteensetting van die uitverkiesing nagegaan word, dan is dit opvallend hoe hy dit beklemtoon dat Jesus Christus nie net 'n teken, 'n openbaring en 'n spieël van God se ewige genade is nie, maar óok die grond en die bewerker van daardie genade wat $\mathrm{Hy}$ vir die mens verwer ${ }^{25}$.

\section{JESUS CHRISTUS DIE SPECULUM ELECTIONIS}

Die uitdrukking dat Jesus Christus die speculum electionis, die spieël van die uitverkiesing is, neem Calvyn van Augustinus oor. Hy neem ook Augustinus se argument oor dat die mens Jesus die duidelikste bewys, die helderste spieël is dat God mense uitverkies sonder dat daardie mense enige verdienste het wat hulle 'n aanspraak op die uitverkiesing sou gee. Immers nòg die mens Jesus nŏg die geslag van Dawid het dit verdien om, verenig met die Woord van God, die eniggebore Seun van God èn seun van die mens te wees. Na sy mensheid het Jesus sèlf géén verdienste gehad op grond waarvan $\mathrm{Hy}$ die Seun van God sou moet wees nie ${ }^{26}$.

Maar ook op 'n tweede manier is Jesus Christus ' $n$ speculum elec- 
tionis. Calvyn stel dan dat indien die mens sekerheid wil hê of hy tot die uitverkorenes behoort of nie, dit nié sal help om God se ewige raadsbesluit te probeer analiseer of daaroor vrae te vra nie. Die mens moet dan na Jesus Christus kyk, hy moet in Hom glo en dan sal hy in Jesus Christus, soos in 'n spieël, die uitverkiesing kan sien ${ }^{27}$. Calvyn gebruik hier die argument dat God die uitverkorenes alleen in Christus van ewigheid af kan liefhê en tot die saligheid uitverkies omdat Jesus Christus hulle, deur sy lyding, dood en opstanding, sou verlos.

Calvyn stel dus óók in die leer van die uitverkiesing die leer van die regverdiging deur die geloof alleen in die sentrum. Deur dit te doen, toon hy aan dat hy heeltemal binne die kader van die hervormingsteologie van die 16 de eeu bly. Dit is eers in die na-bloei van die Hervorming, veral in die $17 \mathrm{de}$ eeu, waar die leer van die regverdiging deur die geloof alleen, geleidelik uit sy sentrale plek verdring word deur die leer van die uitverkiesing. Dit gebeur dan veral daar waar die uitverkiesing aan die leer van die nuwe of weergeboorte gekoppel word.

Dit is veral deur die toedoen van Theodorus Beza, 1519-1605, Calvyn se leerling, medewerker en opvolger aan die Geneefse Akademie, dat die leer van die uitverkiesing die sentrale dogma van die Calvinistiese ortodoksie geword het. Nou word die uitverkiesing by uitstek dié leerstuk waaraan die gelowiges vir hulle sekerheid van die heil kan vashou ${ }^{28}$. Hoewel vir dié aksentsverskuiwing ook 'n beroep gedoen word op Calvyn ${ }^{29}$ èn die Heidelbergse Kategismus ${ }^{30}$, het die Calvinistiese ortodoksie nog verder gegaan en gestel ${ }^{31}$ :

"Indien 'n mens die geskenk van die heiliging ervaar waardeur ons vir die sonde sterf en vir die geregtigheid leef, dan kan hy weet dat hy geregverdig is, dit wil sê dat hy die ware geloof ontvang èn uitverkies is. Tog is dit so dat ek dit alleen deur die genade van God ervaar. So is ek dan geregverdig, geroep èn uitverkies."

Hierdie saak word in die Nederlandse "Nadere Reformatie" verder uitgewerk en hierin blyk ook hoe sterk dié "Nadere Reformatie" deur die Engelse Puritanisme beïnvloed is. So het Amesius, die man wat aan die "Nadere Reformatie" sy teologiese basis gee, die nuwe of weergeboorte saam met die kenmerke van die nuwe lewe, die middelpunt van sy sisteem gemaak. Hier word die uitverkiesing direk aan die leer van die weergeboorte gekoppel. So word Christus en sy werk op die agtergrond geskuif en die Heilige Gees, wat die weergeboorte van die mens bewerkstellig, eensydig op die voorgrond geplaas ${ }^{23}$. Die reformatoriese siening dat die gelowige nuut gebore word, word omgedraai sodat die nuwe of tweede geboorte 'n voorwaarde vir die geloof word. 
Dit is heeltemal anders as by Calvyn wat juis téén hierdie soort denke gewaarsku het. Meerdere male waarsku Calvyn veral teen die opvatting dat as 'n mens nié glo nie dan is dit omdat so 'n mens reeds deur God tot die verderf gepredestineer is. Calvyn se standpunt is om die mens altyd weer op Jesus Christus, die Verlosser, te wys en nie op die "merktekens" van die uitverkiesing nie ${ }^{33}$.

"Want vir elkeen," sê Calvyn, "wat nie op die duidelike pad van die geloof gaan nie, vir hom sal God se uitverkiesing niks anders as 'n dodelike doolhof wees nie. Daarom, sodat ons seker kan wees van die vergewing van die sonde, sodat ons gewete kan rus in die sekerheid van die ewige lewe, sodat ons met vrymoedigheid God Vader kan noem, moet ons nooit dit wat God voor die grondlegging van die wêreld oor ons bepaal het, tot uitgangspunt neem nie. Die beginpunt van ons denke moet God se vaderlike liefde wees soos dit in Christus geopenbaar is èn wat Christus deur die evangelie verkondig."

\section{ENKELE SLOTOPMERKINGS}

Vir die doeleindes van hierdie uiteensetting moet hiermee maar volstaan word. Dit is duidelik dat nie ăl die fasette van die uitverkiesing, soos Calvyn dit na vore bring, hier behandel is nie. So is byvoorbeeld die sonde en die sondigheid van die mens en die feit dat die mens uit necessitas sondig, hier nie genoem nie. Ook nie die hele aangeleentheid van die verhouding van God en die bose nie, om maar net twee sake te noem. Hoewel dit, in die lig van die teologiese konteks waarin ons leef van wesenlike belang is, moet die behandeling daarvan vir ' $n$ ander geleentheid wag.

Met hierdie geleentheid is slegs daarop gewys dat die genadegawe van die geloof in Jesus Christus ook vir Calvyn van primêre betekenis is by die behandeling van die leer van die uitverkiesing. Die geloof, die vertroue op God en sy beloftes is vir Calvyn nooit gegrond op enige kennis in verband met die uitverkiesing nie, maar op die evangelie waarvan Jesus Christus die middelpunt is. Calvyn stel dan ook dat die uitverkiesing wel vóóraf gaan aan die geloof maar dat dit terselfdertyd alleen deur die geloof geken kan word ${ }^{34}$. Die belangrikheid van die uitverkiesing lê dáárin dat dit vir ons mense die oorsprong van die geloof as 'n genadegawe van God duidelik aantoon. Daardie kennis kan daartoe bydra om ons geloof in Jesus Christus te verstewig en te verdiep ${ }^{35}$. So word dit dan ook duidelik waarom Calvyn, in die struktuur van sy teologie, die leer van die uitverkiesing op die bespreking van die geloof laat volg. Juis hier word weer duidelik dat in Calvyn se hele teologiese arbeid die 
klem altyd val op die evangelie, die beloftes van God, op Jesus Christus die Verlosser uit die sonde en die dood.

So gee Calvyn, ook in sy leer van die uitverkiesing, aan God die eer wat Hom toekom. Want die suiwerste uitdrukking van ons plek coram Deo is geloof. Die geloof immers laat God in alles God wees, dit laat God se Woord geld téénoor ons eie wysheid, dit laat die geregtigheid van Christus geld met erkenning van God se oordeel oor al ons menslike eiegeregtigheid.

Die uitverkiesing leer ons óók die geloof, wat die mens op die regte plek voor God plaas, nié ons prestasies is nie maar God se werk. Daarom sê Paulus ook: "Geen mens het dus iets om op te roem voor God nie. Aan God is dit te danke dat julle met Christus Jesus verenig is."

Die leer van die uitverkiesing is ook daar om die mens te verootmoedig. Die enigste wat die mens uit sy verlorenheid kán red, is die geloof, God se werk. Hierin lê terselfdertyd egter 'n groot troos want God se werk wat voortvloei uit sy ewige raad, is onverganklik. Daarom glo ons, op grond van die uitverkiesing, in die volharding van die heiliges. Die leer van die uitverkiesing leer ons ook om iets te begryp van God se barmhartigheid èn regverdigheid. God se geregtigheid in die besluit van die sondeval èn van die verwerping kan Calvyn slegs met bewing glo: decretum horribile, fateor. Tog is dit ' $n$ regverdige besluit want God is regverdig. God se geregtigheid in sy vonnis van die verworpenes is duidelik. Niemand gaan verlore om 'n ànder rede as deur sy sonde en ongeloof nie. Dit is 'n regverdige oordeel wat ons àlmal verdien het. Daarom is dit ook niks anders as barmhartigheid nie as God sommige uit die verdiende oordeel red en ander verbygaan. Ook hierin word God se geregtigheid duidelik want God kies en begenadig die sondaar in Christus. As die sondaar dan deur die geregtigheid van Christus met God versoen is, dan is sy redding slegs uit genade. Soos Calvyn dit stel in sy strydskrif teen Pighius:

"Alle mense het dit gemeenskaplik: dat hulle God verwerp. Niemand wil God gehoorsaam wees as God nie self dit aan die mens gee wat Hy gebied nie.

Want ons word in Ef 2:10 nuwe skepsele genoem omdat God ons gemaak het wat ons nou is om ons lewe te wy aan die goeie dade waarvoor Hy ons bestem het. Ek vra u met nadruk: wat'n ongelyke rol-verdeling sal dit wees as God ons wel as sterflike mense sou geskep het maar elkeen van ons sy eie skepper tot geregtigheid en deelname aan die hemelse lewe sou kon wees? Want as dit so was, dan sou God slegs die eer van 'n onvolmaakte genade hê en dan sou ons die roem wegdra van iets wat in voortreflikheid hoog daar bo uitstyg. 
Nee, die besnydenis van die hart, die herskepping van die mens mag aan niemand anders as aan God alleen toegeken word nie."

Aantekeninge

1. Vgl in hierdie verband $\mathrm{R}$ Sauerzapf, Die Säkularisierung der Genfer Oekumene, DDdiss UP, Pretoria 1975.

2. F Wendel, Calvin. The Origins and Development of his Religious Thought. London 1963, p 357. If we want to speak of a "system" of Calvin, we must do so with certain reservations, owing to the plurality of themes that imposed themselves simultaneously upon it's author's thinking. It is because they have failed to realize this, that the majority of historians have tried to re-construct the Calvinist dogmatic from the standpoint of one central idea supposed to dominate it as a whole. For a long while, as we know, predestination was held to be that idea ... It would be better, we think, to confess that Calvin's is not a closed system elaborated around a central idea, but that it draw together, one after another, a whole series of Biblical ideas, some of which can only with difficulty be logically reconciled.

3. Vgl Joh Calvyn, Institusie van die Christelike godsdiens 1536 , vert deur HW Simpson, Potchefstroom 1980, Hfstk 2.3.4., b.l $143 \mathrm{vg}$.

4. Hier kan verwys word na sy Defensio adversus calumnias Albert Pighii van 1542; sy Contre les Libertins van 1542; sy Advertissement contre l'Astrologie van 1549 en sy Consensus Genevensis van 1552 asook sy Psalmkommentaar van 1557.

5. Vgl Hier LF Schulze, Calvin's reply to Pighius, Potchefstroom 1971, p 139.

6. WH Neuser, Dogma und Bekenntnis in der Reformation, artikel in Handbuch der Dogmen - und Theologiegeschichte, hrsg Carl Andresen, Göttingen 1980, Bd II, s 254.

7. F Wendel, lc, p 269.

8. Joh Calvinus, Institutio christianae religionis 1559, Bk III. 21.1. Die aanhalings wat hier gegee word, is 'n poging om Calvyn se stellings in Afrikaans weer te gee.

9. $\mathrm{Vgl}$ WH Neuser, aaO, S 255.

10. WH Neuser, $a a O, S$ 239: Calvin wurde wie Luther im Occamismus geschult ... Die Feststellung er (di Calvyn) habe nie Theologie studiert, trifft daher die Sachverhalt nicht.

11. Karl Reuter, Das Grundverständnis der Theologie Calvins, Neukirchen Vluyn 1963, S 142-154 en ook $S 157$ ff.

12. WH Neuser, aaO, S 255: Calvins Schwache ist, dass er zwar Providenz und Prädestination trennt, aber diese nicht jener unterordnet und so die soteriologische Linie nicht durchzieht. Die scholastische Systemātik hält ihn fest.

13. Joh Calvinus, $1 c$, III.23.2.

14. Joh Calvinus, lc, III.23. 7-9 en 24:13-14 waar hy oor die ondeurgrondelikheid van God se regverdigheid handel.

15. Joh Calvinus, Ic, I.17. 3-4.

16. Joh Calvinus, $l c$, I.17.3.

17. Joh Calvinus, lc, I.17.4.

18. Joh Calvinus, Ic, I.17.11.

19. Karl Reuter, aaO, S 154: Calvin hat eine reformatorischen Heilserkenntnis gewonnen; aber seine Gotteslehre weist nominalistische Störungen auf.

20. $\mathrm{Vgl}$ in hierdie verband LF Schulze, ic, p 145. Ook W Niesel, Die Theologie Calvins, München 1957, S 68-77. Hier wonder 'n mens of die ou stelreël ook nie hier geld nie naamlik dat as ' $n$ vraag gestel word wat nie vanuit die Skrif beantwoord kan word nie of dit nie 'n verkeerde vraag was nie!

21. Joh Calvinus, $l c$, I.18.4.

22. Joh Calvinus, lc, II. 16.3.

Die slotsin by hierdie aanhaling kom uit Institusie, II.16.4.

23. Joh Calvinus, $l c$, II.17.2. 
24. Joh Calvinus, $l c$, MII.24.5.

25. Joh Calvinus, $l c, 11.17$. Hier beklemtoon Calvyn dit met besondere klem dat Jesus Christus nie nèt die genade van God nie maar óók die ewige saligheid vir ons verdien het.

26. Joh Calvinus, $l c$, II.17.1 en III.22.1.

27. Hier kan verwys word na Joh Calvinus, ic, III.14.20 waar Calvyn sê: . . . want die gelowiges beskou die goeie werke wat hulle doen nie anders as gawes van God nie waaruit hulle sy goedheid leer ken, nie anders as tekens van hulle roeping waaruit hulle hulle verkiesng aflei ...

In sy Kommentaar op I Pet 1:10 merk Calvyn op: Die hoofsaak is dat die kinders van God hulle deur die kenmerk dat hulle vroom en heilig lewe, van die verworpenes sal onderskei. $\mathrm{Vgl}$ in hierdie verband ook $\mathrm{S}$ van der Linde, De Leer van den Heiligen Geest bij Calvijn, Wageningen 1953, bl 110-118, asook W Krusche, Das Wirken des Heiligen Geistes nach Calvin, Göttingen 1957, S 233 ff.

28. $\mathrm{Vgl}$ in hierdie verband C Graafland, De Zekerheid van het Geloof, Wageningen 1961, bl $61 \mathrm{vgg}$. Asook JS Bray, Theodore Beza's doctrine of Predestination, Nieuwkoop 1975, p 107 vg.

29. C Graafland, $a w$, bl 46-51.

30. In die Heidelbergse Kategismus, antw 86 word oa gestel: ... sodat ons vir onsself uit die vrugte van die geloof sekerheid kan kry.

Tog is dit duidelik dat in die Calvinistiese ortodoksie hierdie opmerkings in 'n verkeerde rigting uitgebrei word. $\mathrm{Vgl}$ in hierdie verband ook: W Köhler, Dogmengeschichte, Zürich 1951, Bd II, S 415.

31. Dit is ' $n$ stelling van Joh Wolleb, Christianae theologiae compendium, van 1626 , soos aangehaal by A Adam, Lehrbuch der Dogmengeschichte, Gütersloh 1968, Bd II, S 397.

32. Vgl hiervoor oa C Graafland, aw, bl $138 \mathrm{vg}$ en ook W Goeters, Die Vorbereitung des Pietismus in der Reformierten Kirche der Niederlände bis zur Labadistischen Krisis 1670, Leipzig 1911.

33. Joh Calvinus, lc, III.23.14.

34. Prior quidem fide est electio, sed ex fide discitur.

35. LF Schulze, $l c, \mathrm{p} 119$.

Vgl ook P Jacobs, Praedestination und Verantwortlichkeit bei Calvin, Darmstadt 1973, S 158-159. 